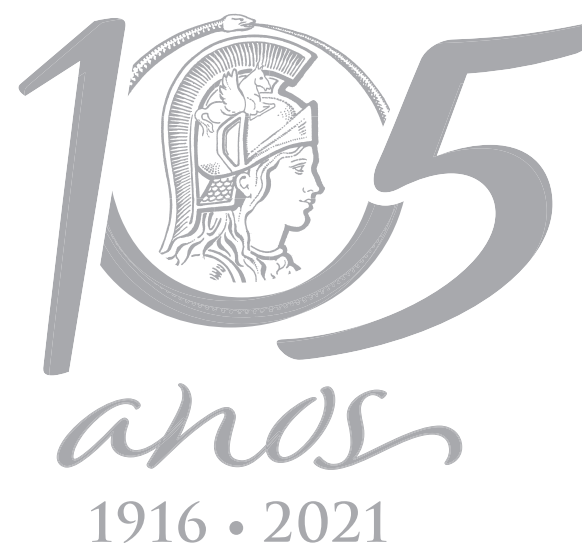

\title{
ECOSYSTEMS
}

\section{Basking and retreat site selection of Phymaturus palluma, a rock-dwelling lizard in the Highlands of Aconcagua}

\author{
NADIA VICENZI, RUBÉN MASSARELLI, NORA IBARGÜENGOYTÍA \& \\ VALERIA CORBALÁN
}

\begin{abstract}
Basking and retreat sites constitute a key resource in the habitat of any ectotherm. Identifying the elements that are used and modelling the microhabitat selection of species is crucial for assessing the impact of anthropogenic disturbances at the population level and, therefore, focusing on conservation efforts. We investigated how structural attributes of the microhabitat and biotic factors influence the probability of basking and retreat sites use by Phymaturus palluma, a rock-dwelling and viviparous lizard endemic to the Central Andes of Argentina. We measured the characteristics of a series of rocks (basking sites) and shelters (retreat sites) in the study area and compared lizard resource use versus availability using resource selection analyses (RSFs). According to our best RSF model, P. palluma select high and large rocks as basking sites and prefer those near their retreat sites and far from the basking sites of their neighbours. In contrast, retreat site selection is related to the length, depth, slope, and width of the shelter. Microhabitat site selection of $P$. palluma is associated with behavioural improvements such as enhancing basking capacity, reducing both intraspecific competition with neighbours and predation risk.
\end{abstract}

Key Words: crevices, microhabitat selection, high-altitude lizard, Liolaemidae, rocks.

\section{INTRODUCTION}

Habitat structure influences several aspects of the life history of an organism, as well as the species' range and abundance (Reinert 1993, Smith \& Ballinger 2001, Goldsbrough et al. 2006). At a large scale, distribution is strongly related to climatic variables (Bozinovic et al. 2011), while at the local scale, microhabitat selection can help to buffer sub-optimal environmental conditions, which is essential to predict species distribution (Huey et al. 2012). Thus, resources that influence decisions about habitat use differ across spatial scales (McMahon et al. 2017). While macrohabitat is defined as the spatial area in which individuals perform all their biological functions, the term microhabitat refers to those environmental variables (e.g., vegetation, structural aspects of rocks and shelters, biotic interactions) that influence the allocation of time and energy of the individual (i.e. that affect individual behaviour) within its macrohabitat (Morris 1987, Jorgensen 2004). Hence, microhabitat selection involves the interplay between abiotic factors, such as rock and shelter characteristics, and biotic factors such as feeding resources, intraspecific competition, and the presence of reproductive females and predators (Huey 1991, Downes \& Shine 1998, Downes 2001). Given the complexity of factors that influence the establishment of species, determining the preference or avoidance of one particular habitat (or microhabitat) in relation to its availability is 
needed to understand the interaction between organisms and their environment (Neu et al. 1974). Moreover, this understanding is of great importance for carrying out actions like habitat restoration, enhancing habitat suitability and other conservation actions for animal species (Huey 1991, Manly et al. 2002, Kacoliris et al. 2009, Croak et al. 2012).

Structural and thermal characteristics of the microhabitats are crucial for ectotherms, since they allow effective behavioural thermoregulation, and could consequently increase or reduce the likelihood of attaining optimal body temperature for performance (Huey et al. 2012, Stellatelli et al. 2014). Rocky outcrops represent an important resource for lizards inhabiting high mountain environments (Hertz \& Huey 1981, Carrascal et al. 1992, Martin \& Salvador 1996). Particularly, for rock-dwelling lizards, rocks offer high availability and diversity of microhabitats, allowing them to satisfy several ecological, physiological and behavioural requirements. For example, the thermal characteristics of rocks vary according to their size, large rocks have lower daily temperature variation compared to small rocks with the same albedo and thermal conductance (Huey et al. 1989, Huey 1991). Hence, crevices formed by large rocks are warmer compared to crevices present in small rocks during the inactivity period (Sabo 2003). Thus, rocky outcrops with variation in rocks size provide spatial thermal heterogeneity, necessary for lizards' thermoregulation. The characteristics of rocks such as size, height, and retreat access, are often found to be the most important habitat attributes affecting the occupancy and abundance of rock-dwelling lizards (Monasterio et al. 2010, Arribas 2013, Ljubisavljević et al. 2017).

Retreat site availability also represents an important resource in microhabitat selection (Block et al. 2012, Croak et al. 2012). Selecting microhabitats with easy access to retreat sites could provide an opportunity for escaping quickly and refuge from predators (Downes \& Shine 1998, Block et al. 2012, Fava \& Acosta 2018), and also, retreat sites with high thermal quality could diminish the cost of hiding (Cooper \& Wilson 2008). Retreat sites play an important role as thermal shelters, reducing the risk of overheating when environmental temperatures are too high (Sinervo et al. 2010, Martín \& Salvador 1996, Vicenzi et al. 2017, 2019, Durán et al. 2018), as well as during brumation (winter dormancy), preventing lizards from freezing when air temperatures drop below $0{ }^{\circ} \mathrm{C}$ (Bishop \& Echternacht 2004).

Vegetation structure has a large influence on the composition and abundance of reptile assemblages (Pelegrin \& Bucher 2012). It plays an important role in behavioural thermoregulation providing thermal heterogeneity and buffering hot and cold temperatures, which ultimately can restrict lizards' activity time (Sunday et al. 2014, Grimm-Seyfarth et al. 2017). Moreover, several studies in Liolaemidae lizards haveshown how the presence of native shrubs favours physiological performance and thermoregulatory behaviour (Stellatelli et al. 2013, 2014). Vegetation also represents a palliative against the predation of lizards (Stamps 1983, Block et al. 2012), acting as an antipredatory shelter (Block et al. 2012), influencing escape tactics (Cooper 1998, Kacoliris et al. 2010), favouring crypsis (Schulte et al. 2004, Block et al. 2012), and offering visual cover that prevents detection by predators while lizards move through their habitat (Kacoliris et al. 2009, Pietrek et al. 2009). Furthermore, in herbivorous species, the structure and composition of vegetation represent the availability of feeding resources (Vitt \& Caldwell 2008). Thus, vegetation cover could represent an essential resource for the thermal, feeding and antipredatory needs of lizards. In this study, we 
assessed different microhabitat features and biotic factors that could influence the selection of basking and retreat sites by P. palluma, and the results may important for the conservation management of the species. We predicted that P. palluma lizards would select: 1) basking sites consisting of high rocks near their retreat sites and vegetative forage to diminish their predation risk, but distant from basking sites used by their neighbours to avoid territorial contests; and, 2) retreat sites formed by deep and long crevices in large rocks to avoid predation.

\section{MATERIALS AND METHODS}

\section{Study species and area}

Phymaturus palluma is a viviparous, rockdwelling and herbivorous lizard endemic to the rocky outcrops of the Central Andes of Argentina, which belongs to the Liolaemidae family (Cei 1986). They live in small groups, composed of one territorial male, one or more females, and juveniles (Videla 1982) which share different microhabitat resources, such as basking sites, shelters and forage sites (Figure 1, Videla 1982, Vicenzi et al. 2019). As other cold-climate lizards, P. palluma activity period is restricted to austral spring and summer, during which lizards thermoregulate by shuttling between rocks directly exposed to the sun and rock crevices (Vicenzi et al. 2019). Rock crevices are used as retreat sites for brumation during the autumnwinter period, and as thermal and antipredatory retreat sites during the activity period. Like other species of the genus Phymaturus, $P$. palluma is considered particularly vulnerable to climate change because of the prediction of substantial reductions in the available habitat over the species' current distributional range in the next 50 years (Sinervo et al. 2010, vicenzi et al. 2017).

The study was conducted in the Vacas Valley in Aconcagua Provincial Park $\left(32.8453^{\circ} \mathrm{S}\right.$, 69.7619 W, WGS84, $2500 \mathrm{~m}$ asl), Mendoza, Argentina. The site belongs to the Altoandina phytogeographic province and is characterized by a cold semiarid climate, according to Köppen classification.

\section{Fieldwork}

We selected a study area $(200 \times 60 \mathrm{~m})$ where microhabitat characteristics were determined. This relatively flat area was characterized by bare soil interspersed with rocks and typical vegetation, such as the shrub genera Tetraglochin and Ephedra, and the grasses Poa and Stipa (Figure 2, Méndez et al. 2006). Three

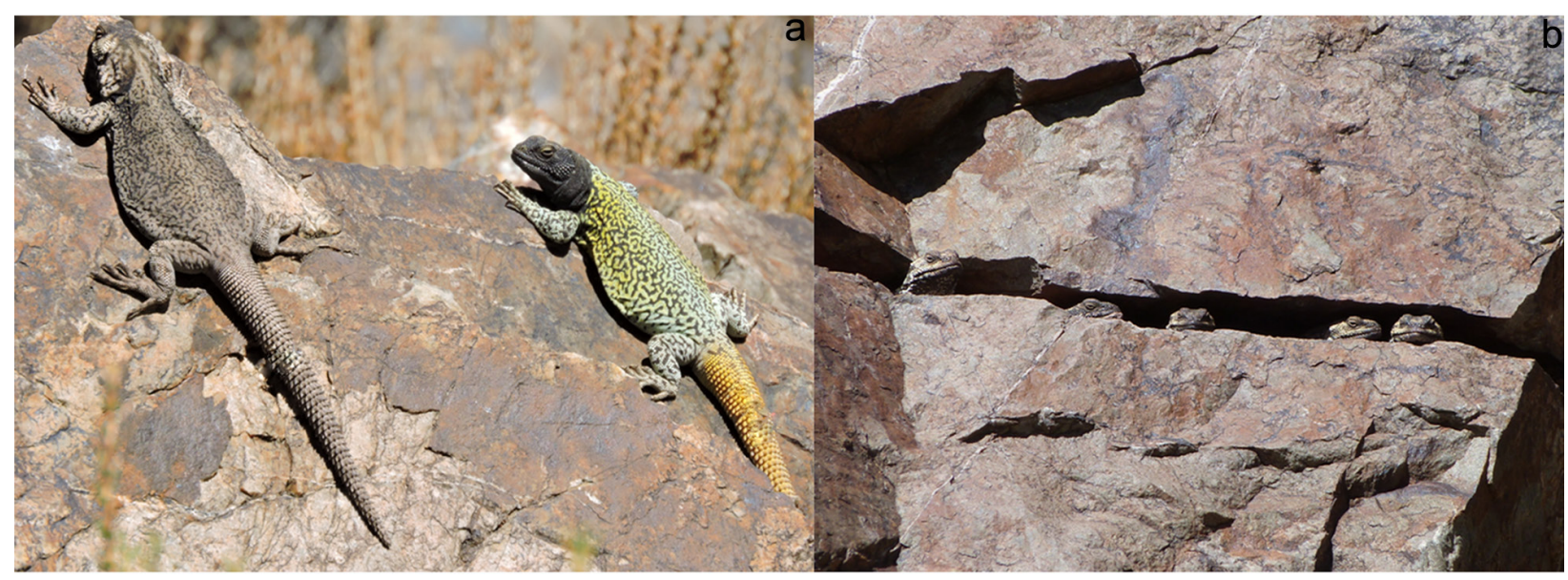

Figure 1. a) Female (lizard at the left of the figure) and male of Phymaturus palluma sharing a basking site. b) Male, females and juveniles sharing a retreat site. 
200-m transects, parallel and 20-m apart, crossed the study area. Microhabitat variables were measured in 100- $\mathrm{m}^{2}$ quadrats located $10-\mathrm{m}$ apart along each transect. We measured a total of 25 quadrats in the study area, and, within each one, we measured the features of all potential basking sites as well as retreat sites present.

The selected population for these analyses were previously studied during the years 20132015, for behaviour and home range research (Vicenzi et al. 2019, N. Vicenzi, unpublished data). This data allowed us to recognize lizards groups and their adjacent neighbours. In addition, based on direct observation of P. palluma lizards, during 2013-2015 sampling period, N.V. registered Tetraglochin alatum, Ephedra sp., greater burnet (Acaena magellanica), field bindweed (Convolvulvus arvensis), alfalfa (Medicago sativa), and dandelion (Taraxacum officinale) as food items of the population (N. Vicenzi, unpublished data). All this data was used to define the biotic variables of the microhabitat selection.

For basking sites, we measured rock height, orientation, slope, and size. We defined three size categories of rocks: (i) small, $<0.1 \mathrm{~m}^{3}$; (ii) medium, 0.1 to $0.6 \mathrm{~m}^{3}$; and (iii) large, $>0.6 \mathrm{~m}^{3}$,

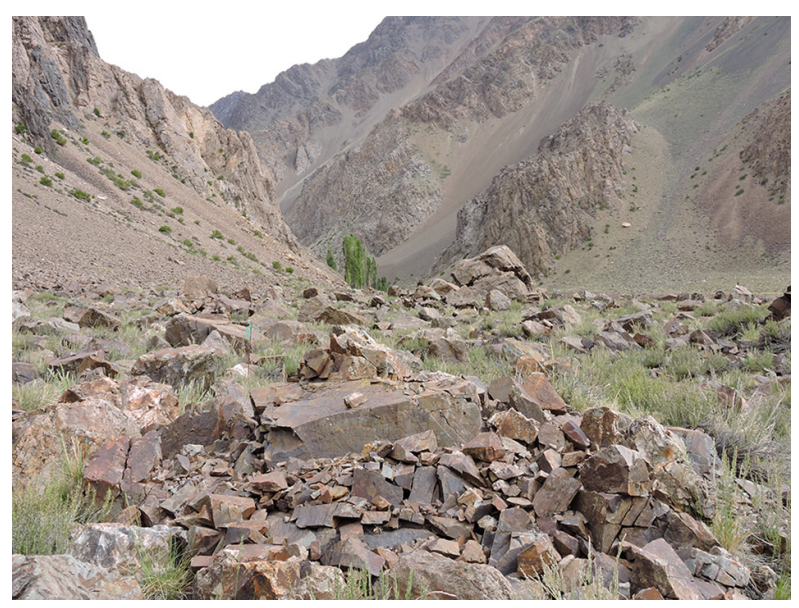

Figure 2. Photograph of rocky outcrops used by the Phymaturus palluma in Punta de Vacas Valley, Mendoza, Argentina. taking into account the variability and frequency of different sizes of rocks present in the study site. The rock size was calculated as the product among rock height, width, and length. We also registered distance to the nearest retreat site, distance to water, distance to the nearest neighbour-lizard basking site, and distance from the closest plant that lizards would use for foraging.

For retreat sites, including natural crevices in rocks and spaces between the bottom of rocks and the substrate, we measured the depth, inclination (using a manual clinometer), length, orientation and width of the shelter, and the size of the rock containing the retreat sites.

A total of six field trips with five-days of duration were conducted in January and March 2015 (sampling period). Four visual surveys per day (at 9.00h, 11.00h, 14.00h and 16.00h) were conducted during the activity period of the lizards, and the use of sites for basking and retreats were recorded. Once a resource unite (rock or shelter) was used by one lizard, the rock was permanently marked to avoid repeated measures (pseudoreplication) at a later time or in another field trip. Thus only the first record of use of a basking or retreat site by a lizard was included in the analysis. Each survey was conducted along the located quadrats along the transects which were walked in opposite directions and without following a consecutive order (for example 3, 1, 2), to avoid disturbing lizards in adjacent transects.

In addition, during December 2015 and January 2016 (a total of 35 days), almost one year after the first survey, the operative temperature $\left(T_{e}\right.$, sensu Bakken 1992) in a sample of basking and retreat sites used by the lizards were measured to evaluate the thermal resources. We placed six physical models (Hertz et al. 1993, Bakken \& Angilleta 2014) calibrated for P. palluma (for details, see Vicenzi et al. 2017 and 
Corbalán et al. 2013) above basking sites formed by each size-class of rocks as well as inside retreat sites located in small, medium and large rocks. We programmed the data loggers to record temperatures every 15 min., and we measured each rock and crevice for seven days. For the analyses of basking sites, we compared 7-day mean $T_{e}$ hourly recorded for each rock $(N=15)$ during the activity period of $P$. palluma (9.00 to $17.00 \mathrm{~h}$ ). For the analyses of retreat sites, we also compared the 7-day mean $\mathrm{T}_{\mathrm{e}}$ per hour recorded in crevices ( $N=15)$ inside small rocks, medium rocks, and large rocks, during activity period (9.00 to $17.00 \mathrm{~h}$ ) and during inactivity time (17.00 to $8.00 \mathrm{~h})$.

\section{Statistical analysis}

We used resource selection functions (RSFs), which are mathematical functions that integrate the joint contribution of multiple predictor variables that influence animal use in a given time and area (Manly et al. 2002, Boyce 2006). RSFs provided estimates that were proportional to the probability of use (Manly et al. 2002). Our measurements were made at the population level, which means that individual information, such as sex, body size or age, was not taken into account in the analyses. Thus, the experimental design used to determine the existence of microhabitat selection corresponded to Type I, according to Manly et al. (2002). Each rock and shelter within the 25 quadrats studied represented a resource unit. Each rock represented a resource unit for the basking sites analyses, whereas each shelter represented a resource unit for the retreat sites analyses. Resource units were categorized as "used" when we registered the presence of a lizard in the unit during the sampling period, and "available" when the resource unit could potentially be encountered by a lizard, but we did not register any lizard using it within the sampling period analyzed (Manly et al. 2002, Lele et al. 2013).

We generated two different RSFs, one for basking sites and one for retreats (Manly et al. 2002, Goldstein et al. 2010, Lele et al. 2013). The first one was employed to estimate the relative probability of lizards selecting a basking site given its size, slope and height, and its distance to a retreat site, to a neighbour basking site, and to vegetation. The second RSF was generated to estimate the relative probability of lizards selecting a retreat site given its depth, inclination, length, orientation, width and the size of the rock that formed the site. Each RSF was obtained using general linear models (GLMs), with a binomial distribution (where "used" was encoded as 1, and "available" as 0). With the first observation of a basking or retreat site used by a lizard, the resource unit was assigned a value of 1 , and subsequent records of use of this basking or retreat site were not registered. We worked at population level, thus each resource unit was analysed once. We started our analyses with a global model that included all variables. To avoid overfitting, because our sample size was small, model comparisons were based on the corrected Akaike Information Criterion (AICC) and were conducted with the function dredge of MuMIn package in R (Legendre \& Legendre 1998, Burnham \& Anderson 2002). According to this function, models are ranked according to their AICC values, and the model with the lowest AICC is considered the best, whereas those with an AICc value difference less than 2 compared to the AICc value of the best model are considered models with substantial support (Burnham \& Anderson 2002). To check multicollinearity in the data, we calculated both with the Pearson correlation test and the variance inflation factors (VIFs). These values were below the traditional thresholds ( $r<0.7$ and VIF $<5$, respectively), suggesting no significant collinearity between 
the variables (Sokal \& Rohlf 1995, Chatterjee et al. 2000). Finally, we estimated the selection ratio (values $>1$ indicate preference and values $<1$ avoidance), the relative probability of use, standard errors and confidence intervals (Cls) for each variable in the final model.

We used the k-fold cross-validation technique to assess the predictive power of each RSF. We split our data into two groups using the sample function in $\mathrm{R}$ (Wiens et al. 2008). Seventy-five percent of our data was used to generate the training data ("model-training"), and $25 \%$ was used to generate the testing data ("model-validation"). The GLM was set using the training data, and estimated coefficients were used to predict values for the testing data set. Predicted values were separated into 10 equalsized categories or bins, scaled between the minimum and maximum values. Then, using a Spearman rank correlation, comparison by bin of the frequencies of predicted values for the test data to the frequencies of observed values was done to evaluate model performance (Boyce et al. 2002, Sawyer et al. 2009, Eads et al. 2011).

To explore the existence of differences in thermal attributes of basking and retreat sites, we compared the hourly mean $\mathrm{T}_{\mathrm{e}}$ of each rock size using an Repetead Measures ANOVA for parametric data and a Friedman test for non-parametric data. All statistical analyses were conducted in R ( $R$ Core Team 2018). The assumptions of normality and homogeneity of variance were checked, using Shapiro-Wilk's and Bartlett's tests, respectively. Means are presented with a \pm standard error (SE). Alpha was set to 0.05 for statistical significance.

\section{RESULTS}

\section{Basking sites}

We recorded and characterized 301 rocks, 121 of which were considered to be used by individuals of P. palluma, whereas 180 remained available. Only three RSF models had a $\triangle \mathrm{AICC} \leq 2$ (Table I). The three models included rock height, distance to crevice and distance to the nearest neighbour rock as explanatory variables. Basking sites used by lizards were $56.9 \pm 3.3 \mathrm{~cm}$ high, $68.5 \pm 10.7 \mathrm{~cm}$ from the retreat site, and $789.3 \pm 32 \mathrm{~cm}$ from the neighbour rock (Figure 3). Basking sites that remained available were $42.5 \pm 1.9 \mathrm{~cm}$ high, 110.6 $\pm 8.5 \mathrm{~cm}$ from the retreat site, and $705.3 \pm 22.4 \mathrm{~cm}$ from the neighbour rock (Figure 3). Based on the top model (Table II; Figure 4), the odds of relative probability of selection increased $1.61 \%$ for every $1-\mathrm{cm}$ increase in rock height, and $0.1 \%$ for every $1-\mathrm{cm}$ increase in distance from neighbour rock; and diminished $0.44 \%$ for every 1 -cm increase in distance from retreat site. Lizards also showed a higher probability of selecting large rocks (148.11\%), despite their low availability (Figure 5). Our model validation confirmed good fit between observed and predicted counts for the final model, with a Spearman rank correlation value of 0.78 .

\section{Retreat sites}

Of the 158 recorded and characterized retreat sites, 64 were considered to be used by individuals of $P$. palluma, whereas 94 remained available. Four RSF models had a $\triangle A I C c \leq 2$ (Table I). All models included the length and width of the retreat site as explanatory variables. Retreat sites used by lizards were $4.14 \pm 0.2 \mathrm{~cm}$ wide, 23.2 $\pm 0.2 \mathrm{~cm}$ long, $0.91 \pm 0.1 \mathrm{rad}$ of inclination, and $37.6 \pm 1.7 \mathrm{~cm}$ deep (Figure 3). Retreat sites that remained available during the sampling period were $5.6 \pm 0.3 \mathrm{~cm}$ wide, $19.2 \pm 1.4 \mathrm{~cm}$ long, $0.95 \pm$ $0.07 \mathrm{rad}$ of inclination, and $25.2 \pm 1.2 \mathrm{~cm}$ deep (Figure 3). Based on the top models (Table II; Figure 4), the odds of relative probability of selection increased $4.3 \%$ for every $1-\mathrm{cm}$ increase in retreat site length and $2.1 \%$ for every $1-\mathrm{cm}$ increase in depth. The probability of selection 
Table I. The three best models of basking sites selection and the four best models of retreat sites for Phymaturus palluma. Model parameters (K), AICc for each model, differences between the model with the lowest AICc and each model ( $\triangle \mathrm{AICC})$ and Akaike Weight.

\begin{tabular}{|c|c|c|c|c|c|}
\hline Microhabitat & Model & K & AICC & $\triangle \mathrm{AICC}$ & Weight \\
\hline \multirow{3}{*}{ Basking site } & $\begin{array}{c}\text { Size }+ \text { Height+ Distance to retreat site }+ \text { Distance } \\
\text { to neighbour }\end{array}$ & 5 & 377.20 & 0.00 & 0.4 \\
\hline & $\begin{array}{c}\text { Height + Distance to retreat site + Distance to } \\
\text { neighbour }\end{array}$ & 4 & 378.54 & 1.3 & 0.21 \\
\hline & $\begin{array}{l}\text { Size }+ \text { Height }+ \text { Distance to retreat site }+ \\
\text { Distance to neighbour + Distance to vegetation }\end{array}$ & 6 & 379.29 & 2.09 & 0.14 \\
\hline \multirow{4}{*}{ Retreat Site } & Width + Length & 2 & 200.7 & 0.00 & 0.27 \\
\hline & Width + Length + Inclination & 3 & 200.8 & 0.08 & 0.26 \\
\hline & Width + Length + Inclination + Depth & 4 & 201.3 & 0.69 & 0.20 \\
\hline & Width + Length + Depth & 3 & 202 & 1.24 & 0.15 \\
\hline
\end{tabular}

diminished $26.58 \%$ for every $1-\mathrm{cm}$ increase in retreat site width and $35.1 \%$ for every radian increase in inclination. Only the model that considered length, width, depth, and inclination of the retreat site as explanatory variables confirmed a medium fit between observed and predicted counts, with a Spearman rank correlation value of 0.52 .

\section{Thermal characterization of basking and retreat sites used by lizards}

During the activity time of lizards (from 09.00 to $17.00 \mathrm{~h}$ ), the $T_{e}$ of the rocks used as basking sites varied according to the size of the rock and hour. Small rocks were the hottest (mean $=38.91^{\circ} \mathrm{C}$ ), medium rocks had an intermediate temperature $\left(\right.$ mean $\left.=33.8^{\circ} \mathrm{C}\right)$, and large rocks were the coldest $\left(\right.$ mean $=31.87^{\circ} \mathrm{C}$; RMANOVA: $F_{\text {rock }}$ size 2, $34=379.66, \quad P<0.001$; Bonferroni Test $t_{\text {small }}$ - Medium $=5.11, \mathrm{t}_{\text {Small }- \text { Large }}=7.04, \mathrm{t}$ Large- Medium $=1.93$, $P<0.001)$. Differences among hours were also statistical significant $\left(F_{\text {hour 8, 34 }}=35.93, P<0.001\right)$, as the interaction of rock size and hour of the day (Table III; $F_{\text {rock size- hour 16, 34 }}=12.89, \mathrm{P}<0.001$ ).

During the activity time of lizards, the $\mathrm{T}_{\mathrm{e}}$ of the crevices used as retreat sites varied according to the size of the rock and the hour of the day small rocks had the hottest crevices (mean $=30.01^{\circ} \mathrm{C}$, , medium rocks had crevices with an intermediate temperature (mean = $23.86^{\circ} \mathrm{C}$ ), and large rocks had the coldest (mean $=21.19^{\circ} \mathrm{C}$; RMANOVA: $F_{\text {rock size 2, } 34}=319.87, \mathrm{P}<0.001$; Bonferroni Test $t_{\text {Small - Medium }}=6.15, \mathrm{t}_{\text {Small - Large }}=8.82$, $\left.\mathrm{t}_{\text {Large- Medium }}=2.67, \mathrm{P}<0.001\right)$. Differences among hours were also statistical significant $\left(F_{\text {hour } 8 \text {, }}\right.$ $\left.{ }_{34}=81.71, \mathrm{P}<0.001\right)$, as the interaction of rock size and hour of the day (Table III; $F_{\text {rock size- hour } 16,}$ $\left.{ }_{34}=41.39, P<0.001\right)$. During the inactivity period (from 18.00 to $8.00 \mathrm{~h}$ ), the $T_{e}$ of the crevices was also related to the size of the rock and the hour of the day. Small rocks had the coldest crevices ( median $\left.=18.11^{\circ} \mathrm{C}\right)$, medium rocks had crevices with an intermediate temperature (median $=20.09^{\circ} \mathrm{C}$ ), and large rocks had the hottest (median $=20.28^{\circ} \mathrm{C}$; Friedman Repeated Measures Analysis of Variance on Ranks, $X_{2,495}=603.36, P<$ 0.001; Bonferroni Test $\mathrm{t}_{\text {Small - Medium }}=0.69, \mathrm{t}_{\text {Small - Large }}$ $\left.=0.87, t_{\text {Large- Medium }}=1.56, P<0.001\right)$.). Difference among hours in each crevice were also statistical significant (Friedman Test Repeated Measures Analysis of Variance on Ranks, $X_{44,495}=1343.7$, $P<0.001)$. 
Basking site
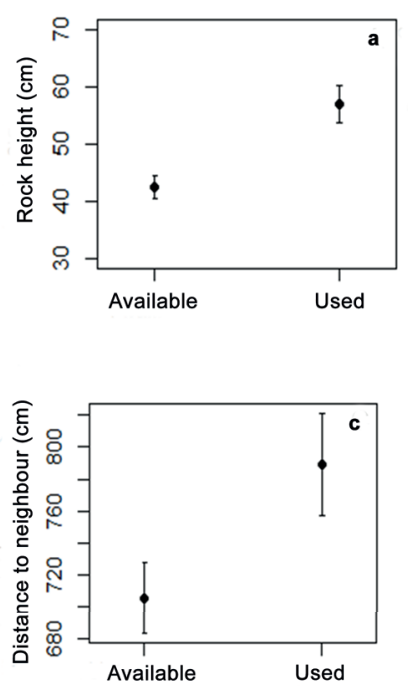
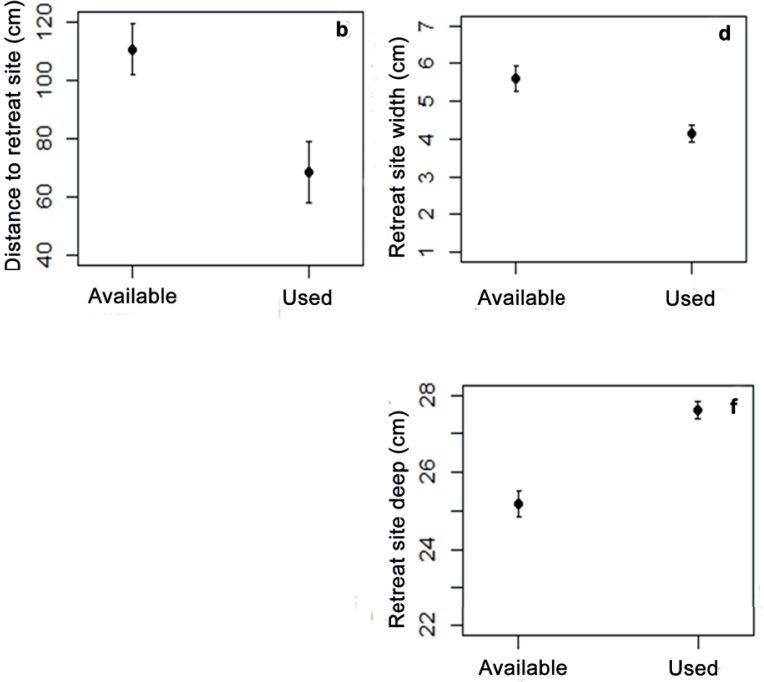

Retreat site
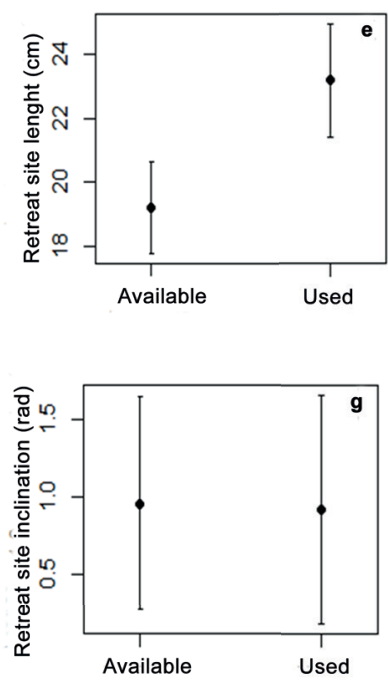

Figure 3. Mean and standard error plot of available versus used resource units for basking sites and retreat sites. For basking sites a) Rock height (available $=42.5 \pm 1.9 \mathrm{~cm}$; used $=56.9 \pm 3.3 \mathrm{~cm}$ ); b) Distance to retreat site (available $=110.6 \pm 8.5 \mathrm{~cm}$, used $=68.5 \pm 10.7 \mathrm{~cm}$ ) and c) Distance to neighbour perch (available $=705.3 \pm 22.4$ $\mathrm{cm}$, used $=789.3 \pm 32 \mathrm{~cm}$ ). For retreat sites d) Retreat site width (available $=5.6 \pm 0.3 \mathrm{~cm}$; used $=4.14 \pm 0.2 \mathrm{~cm}$ ); e) Retreat site length (available $=19.2 \pm 1.4 \mathrm{~cm}$; used $=23.2 \pm 0.2 \mathrm{~cm}$ ); f) Retreat site deep (available $=25.2 \pm 1.2 \mathrm{~cm}$; used = $37.6 \pm 1.7 \mathrm{~cm}$ ) and, g) Retreat site inclination (available = $0.95 \pm 0.07 \mathrm{rad}$; used = $0.91 \pm 0.1 \mathrm{rad}$ ).

Table II. The best model of basking site and retreat site selection for Phymaturus palluma. Coefficients, standard error (SE), selection ratio ( $>1$ selected resource, $<1$ avoided resource), probability of selection (\%), probability ( $P$ ) and confidence intervals $(\mathrm{Cl})$ with 0.95 of significance.

\begin{tabular}{|c|c|c|c|c|c|c|c|c|}
\hline Microhabitat & Variable & Coefficient & SE & $\begin{array}{l}\text { Selection } \\
\text { ratio }\end{array}$ & $\begin{array}{l}\text { Probability } \\
\text { of selection }\end{array}$ & $P(>|z|)$ & $\mathrm{CI}$ lower & $\begin{array}{c}\mathrm{Cl} \\
\text { upper }\end{array}$ \\
\hline \multirow{6}{*}{ Basking site } & $\begin{array}{c}\text { Rock } \\
\text { Intercept }\end{array}$ & 0.02 & 0.45 & 1.02 & 1.62 & $<0.05$ & 0.004 & 0.03 \\
\hline & Small rock & -1.52 & 0.01 & 0.21 & -78.07 & 0.12 & -2.43 & -0.65 \\
\hline & $\begin{array}{l}\text { Medium } \\
\text { rock }\end{array}$ & -0.24 & 0.32 & 0.78 & -21.53 & 0.45 & -0.87 & 0.38 \\
\hline & Large rock & 0.91 & 0.63 & 2.48 & 148.12 & 0.15 & -0.31 & 2.19 \\
\hline & Retreat site & -0.004 & 0.001 & 0.99 & -0.44 & $<0.05$ & -0.007 & -0.002 \\
\hline & $\begin{array}{l}\text { Neighbour } \\
\text { rock }\end{array}$ & 0.001 & 0.0004 & 1.01 & 0.1 & $<0.05$ & 0.0001 & 0.002 \\
\hline \multirow{5}{*}{ Retreat site } & Intercept & 0.68 & 0.51 & - & & 0.5 & -0.68 & 1.3 \\
\hline & Width & -0.32 & 0.08 & 0.73 & -26.58 & $<0.05$ & $-0,5$ & -0.16 \\
\hline & Length & 0.04 & 0.01 & 1.04 & 4.3 & $<0.05$ & 0.004 & 0.06 \\
\hline & Inclination & -0.4 & 0.27 & 0.65 & 35.1 & 0.1 & -0.98 & 0.08 \\
\hline & Depth & 0.02 & 0.01 & 1.02 & 2.1 & 0.2 & -0.01 & 0.05 \\
\hline
\end{tabular}



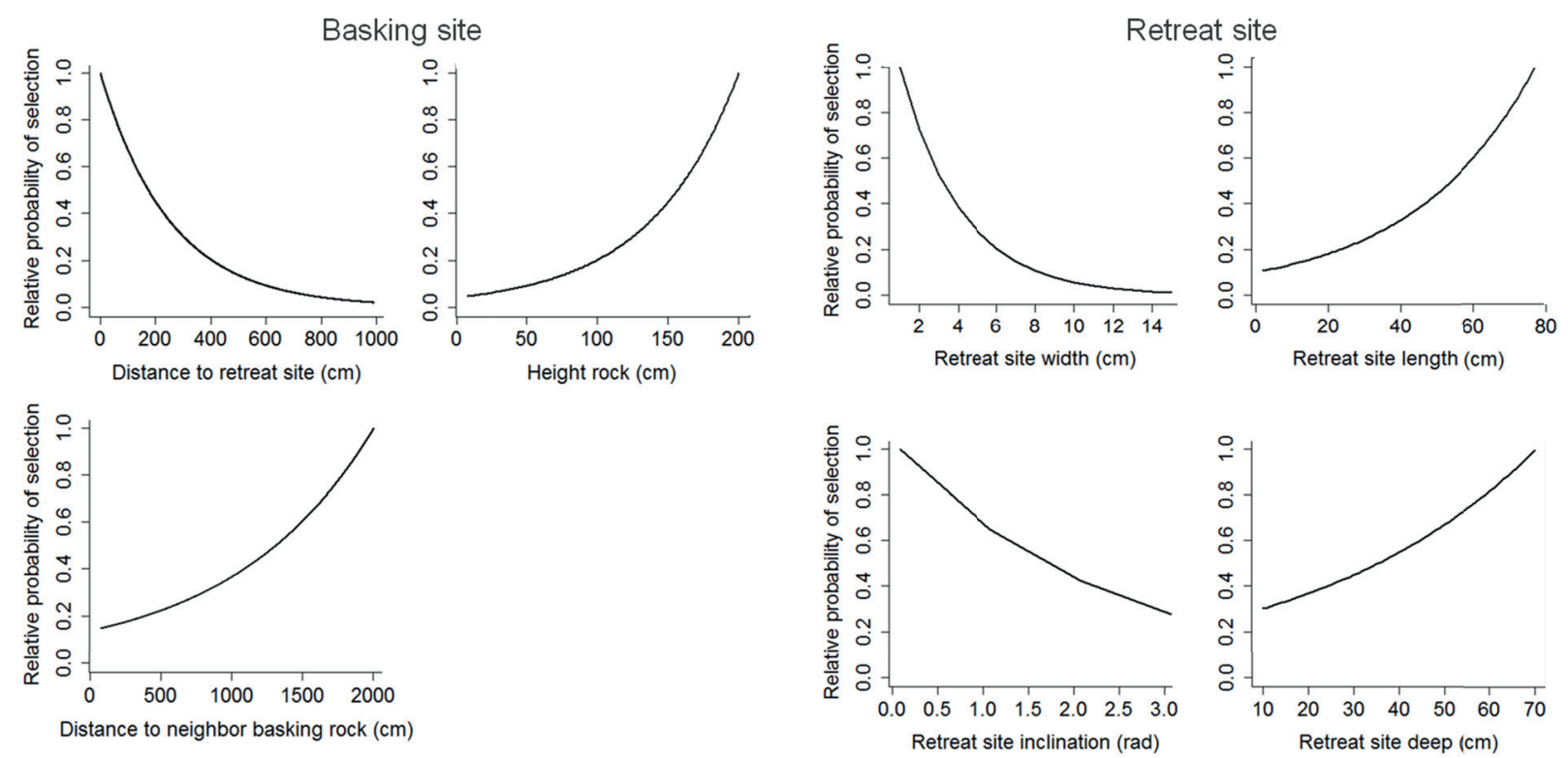

Figure 4. Plots showing the relative probability of basking site selection and retreat site selection of Phymaturus palluma assuming all other variables were held constant at their respective median, for the most important variables in the RSF models with a $\Delta$ AICC $\leq 2$.

\section{DISCUSSION}

The selection of basking and retreat sites by $P$. palluma was influenced by abiotic features of the rocks and shelters, such as size and structure and by biotic factors, such as distance to conspecifics. Consistent with our predictions, P. palluma selected basking sites formed by high and large rocks, near retreat sites and far from the basking sites of their neighbours, whereas retreat sites selected were formed by narrow, depth and long shelters.

The relative probability of selection of basking sites of P. palluma increased $148.12 \%$ when the rock was large (more than $>0.6 \mathrm{~m}^{3}$ ). Several studies have demonstrated that the rock dimension is an important component of the selection of microhabitats (Huey 1991, Kearney 2002, Quirt et al. 2006, Ljubisavljević et al. 2017). In high-mountain lizards, such as P. palluma, the selection of certain features of basking sites could optimize thermoregulatory opportunity (Huey 1982, Van Damme et al. 1989), which is important because it enables lizards to reach body temperatures near the preferred temperature range, despite the extreme and variable air temperatures. In our study site, large rocks were colder than small ones, and both medium and large rocks exhibited mean

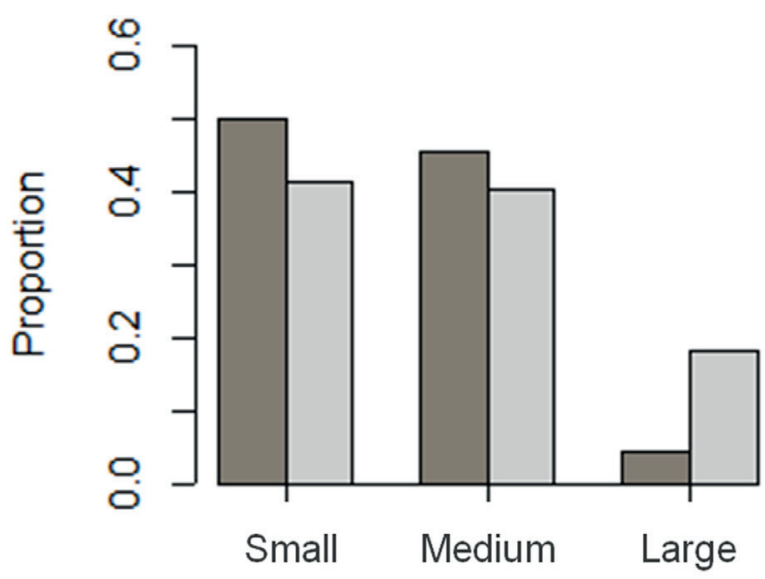

\section{Rock Size}

Figure 5. Histogram of proportions of Available versus Used basking sites according to the type of rock (small, medium and large). 
temperatures, $33.8^{\circ} \mathrm{C}$ and $31.87^{\circ} \mathrm{C}$ respectively, below the set point of preferred temperature of the species $\left(34.24-36.11^{\circ} \mathrm{C}\right.$, Vicenzi et al. 2017), whereas temperature of small rocks showed a mean of $38.91^{\circ} \mathrm{C}$, near the critical maximum for the species $\left(41.18^{\circ} \mathrm{C}\right.$, Vicenzi et al. 2017). Thus, by selecting large rocks, lizards could avoid overheating, and consequently, reduce the costs of thermoregulation. However, rock features which could optimize the heat gain of lizards by solar radiation, such as orientation and slope of the perch (Muth 1977, Ribeiro et al. 2009), did not influence basking site selection.

The advantage of selecting higher rocks that facilitates vigilance, and therefore enabling lizards to scan the environment more effectively and detect other individuals (Avery 1991), could also be a disadvantage, as it may increase their conspicuousness, especially to predators (Zucker 1986, Radder et al. 2005). One way to reduce predation risk is basking near retreat sites. Our results demonstrated that the probability of selection of basking sites by $P$. palluma increases when rocks have available retreat sites at a minimum of $1 \mathrm{~m}$ distance, as was observed in Iberolacerta monticola and Podarcis hipanica (Martin \& Salvador 1996, Diego-Rasilla \& Perez-Mellado 2003). This could reduce predation risk (Carrascal et al. 1992), especially during the early morning when locomotor performance of lizards is low (Van Damme et al. 1989, Carrascal et al. 1992). Previous studies registered that in the mornings, P. palluma uses sun exposed crevices to start basking behaviour, which gives the lizards the opportunity to increase their body temperature without exposing themselves to predators (Vicenzi et al. 2019). During the day, however, the selection of basking sites near retreat sites could also be related to thermoregulation needs, such as avoiding overheating risk during the summer. Several studies about thermoregulation in Phymaturus species have shown that these lizards thermoregulate shuttling between rocks and rock crevices (Durán et al. 2018, Vicenzi et al. 2019), thus short distances between basking and retreat sites could diminish thermal risks. In addition, this thermoregulatory behaviour

Table III. Operative temperature (Mean \pm SE) of small, medium and large rocks and crevices within each of them per hour during activity period of Phymaturus palluma.

\begin{tabular}{|c|c|c|c|c|c|c|}
\hline Hour & $\begin{array}{c}\text { Small rock } \\
\left.\mathbf{(}{ }^{\circ} \mathbf{C}\right)\end{array}$ & $\begin{array}{c}\text { Medium } \\
\text { rock }\left({ }^{\circ} \mathbf{C}\right)\end{array}$ & $\begin{array}{c}\text { Large rock } \\
\mathbf{(} \mathbf{C})\end{array}$ & $\begin{array}{c}\text { Crevice within } \\
\text { small rock }\left({ }^{\circ} \mathbf{C}\right)\end{array}$ & $\begin{array}{c}\text { Crevice within } \\
\text { medium rock }\left({ }^{\circ} \mathbf{C}\right)\end{array}$ & $\begin{array}{c}\text { Crevice within } \\
\text { large rock }\left({ }^{\circ} \mathbf{C}\right)\end{array}$ \\
\hline $\mathbf{9 . 0 0}$ & $31.59 \pm 0.86$ & $27.15 \pm 0.72$ & $24.31 \pm 0.61$ & $21.35 \pm 0.59$ & $16.43 \pm 0.39$ & $17.4 \pm 0.37$ \\
\hline $\mathbf{1 0 . 0 0}$ & $36.91 \pm 0.96$ & $30.79 \pm 0.85$ & $28.05 \pm 0.78$ & $29.62 \pm 0.81$ & $17.78 \pm 0.38$ & $18.32 \pm 0.39$ \\
\hline $\mathbf{1 1 . 0 0}$ & $40.96 \pm 0.84$ & $33.54 \pm 0.85$ & $31.18 \pm 0.84$ & $33.58 \pm 0.83$ & $19.65 \pm 0.41$ & $19.40 \pm 0.41$ \\
\hline $\mathbf{1 2 . 0 0}$ & $43.15 \pm 1.03$ & $35.09 \pm 0.79$ & $33.35 \pm 0.91$ & $32.93 \pm 0.79$ & $23.39 \pm 0.74$ & $20.62 \pm 0.42$ \\
\hline $\mathbf{1 3 . 0 0}$ & $43.38 \pm 1.32$ & $36.24 \pm 0.95$ & $34.46 \pm 1.02$ & $32.51 \pm 0.87$ & $24.98 \pm 0.71$ & $21.92 \pm 0.51$ \\
\hline $\mathbf{1 4 . 0 0}$ & $43.06 \pm 1.23$ & $36.96 \pm 0.91$ & $35.4 \pm 0.99$ & $32.28 \pm 0.89$ & $26.33 \pm 0.65$ & $22.75 \pm 0.5$ \\
\hline $\mathbf{1 5 . 0 0}$ & $40.61 \pm 1.3$ & $36.74 \pm 0.87$ & $35.35 \pm 0.94$ & $31.02 \pm 0.88$ & $27.72 \pm 0.65$ & $23.26 \pm 0.46$ \\
\hline $\mathbf{1 6 . 0 0}$ & $38.43 \pm 1.01$ & $35.52 \pm 0.89$ & $33.97 \pm 0.92$ & $29.5 \pm 0.7$ & $28.93 \pm 0.66$ & $23.5 \pm 0.47$ \\
\hline $\mathbf{1 7 . 0 0}$ & $32.13 \pm 0.9$ & $32.19 \pm 1.1$ & $30.78 \pm 1.01$ & $27.27 \pm 0.61$ & $29.52 \pm 0.76$ & $23.50 \pm 0.48$ \\
\hline
\end{tabular}


of Phymaturus, could explain why distance to vegetation was not influence basking site selection.

Retreat sites were selected according to their attributes, such as length, depth, slope, and width. The flattened body morphology and the spiny tail of all Phymaturus species are associated with adaptative advantages of retreating into narrow rocky crevices where they are protected from predators (Debandi et al. 2012). Thus, the selection of long crevices could facilitate the quicky access of lizards to crevices, whereas the selection of deep and narrow crevices with low slope could help to avoid Agriornis birds predation, the main predator of P. palluma (Videla 1982). Some retreat site features, such as orientation and rock size, could influence the thermal regime of the shelter (Kearney 2002). Despite the operative temperature inside crevices being highly related to rock size, this characteristic did not influence the selection by individuals of P. palluma, in contrast to the results by other authors for in Sceloporus occidentalis (Sabo 2003) and Oedura lesueurii (Croak et al. 2008). This result suggests that predator avoidance is more important than thermal requirements when P. palluma lizards select retreat sites, at least during the activity time periods (from 9.00 to $17.00 \mathrm{~h}$ ), as was observed by Downes \& Shine (1998), in the habitat selection experiment carried out in the gecko Oedura lesuerii. During the night, crevices in large rocks attain higher $\mathrm{T}_{\mathrm{e}}$ (median= $20.08^{\circ} \mathrm{C}$ ) than small ones ( median $=18.11^{\circ} \mathrm{C}$ ), and large rocks likely represent better refuges both during summer nights and during the winter. Unfortunately, we could not evaluate selection of retreat sites during these periods. Further research should include a profound thermal characterization of the microhabitat related to the thermal biology of the individuals, such as the implications of the biotic interactions in the population since these factors are likely to affect microhabitat selection.

The knowledge of microhabitat features allows the identification of key resources impacting population persistence, and is crucial for conservation management (Ljubisavljević et al. 2013), especially for species with specific microhabitat requirements, such as those belonging to the genus Phymaturus (Abdala et al. 2012, Debandi et al. 2012). Our study strongly reinforces the important role of the structure and morphology of the rocks and shelters for the selection of basking and retreat sites on rockdwelling lizards. Rocky outcrops offer thermal heterogeneity, necessary not only to enhance thermoregulation but also to prevent lizards from overheating. Particularly, for P. palluma, a species whose current habitat is predicted to be reduced by $86 \%$ over the next 50 years (Vicenzi et al. 2017), the results of this study may contribute to management decisions based on the characteristics of the basking and retreat sites selected by P. palluma, to conserve future sites thermally suitable for the species and also to enhance basking and retreat site availability in current degraded habitat.

\section{Acknowledgments}

We thank to Ryan Nielson and Mary Rowland for their help in design and statistical analyses and to Dr. John D. Krenz and two anonymous reviewers for their insightful review of the manuscript. Thanks to the Dirección de Recursos Naturales Renovables of Mendoza and park rangers of the Aconcagua Provincial Park and IADIZA for their support in conducting this research. All procedures were performed with the permission of the provincial authority (Dirección de Recursos Naturales Renovables, Res. Nos. 625/2013 and 02/2015), and complied with Argentinian National Law 14346 on animal care. This study was financed by the Consejo Nacional de Investigaciones Científicas y Técnicas (CONICET) and Agencia Nacional de Promoción Científica y Tecnológica (FONCYT: PICT 2013-1139, PICT 2014-3100). 


\section{REFERENCES}

ABDALA CS ET AL. 2012. Categorización del estado de conservación de las lagartijas y anfisbenas de la República Argentina. Cuad Herpetol 26: 215-248.

ARRIBAS OJ. 2013. Thermoregulation, activity and microhabitat selection in the rare and endangered Batuecan Rock Lizard, Iberolacerta martinezricai (Arribas, 1996). Herpetozoa 26: 77-90.

AVERY RA. 1991. Temporal dynamics of a vigilance posture in the ruin lizard Podarcis sicula. Amphib Reptil 12: 352-356.

BAKKEN GS. 1992. Measurement and application of standard and operative temperatures in ecology. Am Zool 32: 194-216.

BAKKEN GS \& ANGILLETTA MJ. 2014. How to avoid errors when quantifying thermal environments. Funct Ecol 28: 96-107.

BISHOP DC \& ECHTERNACHT AC. 2004. Emergence behavior and movements of winter-aggregated Green Anoles (Anolis Carolinensis) and the thermal characteristics of their crevices in Tennessee. Herpetologica 60: 168-177.

BLOCK C, VEGA LE \& STELLATELLI OA. 2012. Vegetation refuges of a sand lizard assemblage in temperate coastal sand dunes. J Herpetol 46: 608-613.

BOYCE MS. 2006. Scale for resource selection functions. Divers Distrib 12: 269-276.

BOYCE MS, VERNIER PR, NIELSEN SE \& SCHMIEGELOW FKA. 2002. Evaluating resource selection functions. Ecol Model 157: 281-300.

BOZINOVIC F, CALOSI P \& SPICER JI. 2011. Physiological Correlates of Geographic Range in Animals. Annu Rev Ecol Evol Syst 42: 155-179.

BURNHAM KP \& ANDERSON DR. 2002. Model selection and multimodel inference: a practical information-theoretic approach. $2^{\text {nd }}$ ed., Springer Verlag, Inc. New York, p. 515.

CARRASCAL LM, LÓPEZ P, MARTÍN J \& SALVADOR A. 1992. Basking and antipredator behaviour in a high altitude lizard: implications of heat-exchange rate. Ethology 92: 143-154.

CEI JM. 1986. Reptiles del centro, centro-oeste y sur de la Argentina. Herpetofauna de las zonas áridas y semiáridas. Monogr Mus Reg Sci Nat Torino 4: 1-527.

CHATTERJEE S, HADI AS \& PRICE B. 2000. Regression analysis by example. $5^{\text {th }}$ Ed, Wiley, New York, p. 421.
COOPER WE JR. 1998. Effects of refuge and conspicuousness on escape behavior by the broad-headed skink (Eumeces laticeps). Amphib Reptil 19: 103-108.

COOPER WE JR \& WILSON DS. 2008. Thermal cost of refuge use affects refuge entry and hiding time by striped plateau lizards Sceloporus virgatus. Herpetologica 64: 406-412.

CORBALÁN V, DEBANDI G \& KUBISCH E. 2013. Thermal ecology of two sympatric saxicolous lizards of the genus Phymaturus from the Payunia region (Argentina). J Therm Biol 38: 384-389.

CROAK BM, PIKE DA, WEBB JK \& SHINE R. 2008. Threedimensional crevice structure affects retreat site selection by reptiles. Anim Behav 76: 1875-1884.

CROAK BM, PIKE DA, WEBB JK \& SHINE R. 2012. Habitat selection in a rocky landscape: experimentally decoupling the influence of retreat site attributes from that of landscape features. PLoS ONE 7: e37982.

DEBANDI G, CORBALÁN V, SCOLARO JA \& ROIG-JUÑENT SA. 2012. Predicting the environmental niche of the genus Phymaturus: Are palluma and patagonicus groups ecologically differentiated? Austral Ecol 37: 392-400.

DIEGO-RASILLA FJ \& PÉREZ-MELLADO V. 2003. Home range and habitat selection by Podarcis hispanica (Squamata, Lacertidae) in Western Spain. Folia Zool 52: 87-98.

DOWNES S. 2001. Trading heat and food for safety: costs of predator avoidance in a lizard. Ecology 82: 2870-2881.

DOWNES S \& SHINE R. 1998. Heat, safety or solitude? Using habitat selection experiments to identify a lizard's priorities. Anim Behav 55: 1387-1396.

DURAN F, KUBISCH EL \& BORETTO JM. 2018. Thermal physiology of three sympatric and syntopic Liolaemidae lizards in cold and arid environments of Patagonia (Argentina). J Comp Physiol B Biochem Syst Environ Physiol 188: 141-152.

EADS DA, MILLSPAUGH JJ, BIGGINS DE, LIVIERI TM \& JACHOWSKI DS. 2011. Postbreeding resource selection by adult blackfooted ferrets in the Conata Basin, South Dakota. J Mammal 92: 760-770.

FAVA GA \& ACOSTA JC. 2018. Escape distance and escape latency following simulated rapid bird attacks in an Andean lizard, Phymaturus williamsi. Behaviour 55: 861-881.

GOLDSBROUGH CL, SHINE R \& HOCHULI DF. 2006. Factors affecting retreat-site selection by coppertail skinks (Ctenotus taeniolatus) from sandstone outcrops in eastern Australia. Austral Ecol 31: 326-336. 
GOLDSTEIN MI, POE AJ, SURING LH, NIELSON RM \& McDonald TL. 2010. Brown bear den habitat and winter recreation in South-Central Alaska. J Wildl Manage 74: 35-42.

GRIMM-SEYFARTH A, MIHOUB JB \& HENLE K. 2017. Too hot to die? The effects of vegetation shading on past, present, and future activity budgets of two diurnal skinks from arid Australia. Ecol Evol 7: 6803-6813.

HERTZ PE \& HUEY RB. 1981. Compensation for altitudinal changes in the thermal environment by some Anolis lizards on Hispaniola. Ecology 62: 515-521.

HERTZ PE, HUEY RB \& STEVENSON RD. 1993. Evaluating temperature regulation by field-active ectotherms: The fallacy of the inappropriate question. Am Nat 142: 796-818.

HUEY RB. 1982. Temperature, physiology, and the ecology of reptiles. In: Gans C \& Pough FH (Eds), Biology of reptilia, Academic Press, New York, p. 25-74.

HUEY RB. 1991. Physiological consequences of habitat selection. Am Nat 137: s91-s115.

HUEY RB, KEARNEY MR, KROCKENBERGER A, HOLTUM JA, JESS M \& WILLIAMS SE. 2012. Predicting organismal vulnerability to climate warming: roles of behaviour, physiology and adaptation. Philos Trans R Soc B Biol Sci 367: 1665-1679.

HUEY RB, PETERSON CR, ARNOLD SJ \& PORTER WP. 1989. Hot rocks and not-so-hot rocks: Retreat-site selection by Garter Snakes and its thermal consequences. Ecology 70: 931-944.

JORGENSEN EE. 2004. Small mammal use of microhabitat reviewed. J Mamm 85(3): 531-539.

KACOLIRIS FP, CELSI CE \& MONSERRAT AL. 2009. Microhabitat use by the sand dune lizard Liolaemus multimaculatus in a pampean coastal area in Argentina. Herpetol J 19: 61-67.

KACOLIRIS FP, MOLINARI A \& WILLIAMS J. 2010. Selection of key features of vegetation and escape behavior in the Sand Dune Lizard (Liolaemus multimaculatus). Anim Biol 60: 157-167.

KEARNEY MR. 2002. Hot rocks and much-too-hot rocks: Seasonal patterns of retreat-site selection by a nocturnal ectotherm. J Therm Biol 27: 205-218.

KEARNEY MR. 2013. Activity restriction and the mechanistic basis for extinctions under climate warming. Ecol Lett 16: 1470-1479.

LEGENDRE P \& LEGENDRE L. 1998. Numerical Ecology. $2^{\text {nd }}$ Ed. Elsevier Science, Amsterdam.
LELE SR, MERRILL EH, KEIM I \& BOYCE MS. 2013. Selection, use, choice and occupancy: Clarifying concepts in resource selection studies. J Anim Ecol 82: 1183-1191.

LJUBISAVLJEVIĆ K, POLOVIĆ L, IKOVIĆ V, VUKSANOVIĆ S \& VUKOV TD. 2017. Habitat use of endemic Balkan rock lizards (Dinarolacerta spp.). Salamandra 53: 279-284.

MANLY BFJ, MCDONALD LL, THOMAS DL, MCDONALD TL \& ERICKSON WP. 2002. Resource Selection by Animals. 2nd edn. Kluwer Academic Publishers. New York, Boston Dordrecht, London, Moscow.

MARTIN J \& SALVADOR A. 1996. Microhabitat selection by the iberian rock lizard Lacerta monticola: Effects on density and spatial distribution of individuals. Biol Conserv 79 : 303-307.

MCMAHON LA, RACHLOW JL, SHIPLEY LA, FORBEY JS \& JOHNSON TR. 2017. Habitat selection differs across hierarchical behaviors: selection of patches and intensity of patch use. Ecosphere 8(11): e01993.10.1002/ecs2.1993.

MÉNDEZ E, MARTínEZ E \& PERALTA I. 2006. La Vegetación del Parque Provincial Aconcagua (Altos Andes centrales de Mendoza , Argentina). Bol Soc Arg Bot 41: 41-69.

MONASTERIO C, SALVADOR A \& DÍAZ JA. 2010. Competition with wall lizards does not explain the alpine confinement of Iberian rock lizards: an experimental approach. Zoology 113: $275-282$

MORRIS DW. 1987. Ecological scale and habitat use. Ecology 68: 362-369.

MUTH A. 1977. Thermoregulatory postures and orientation to the sun: a mechanistic evaluation for the zebra-tailed lizard, Callisaurus draconoides. Copeia 1977: 710-720.

NEU CW, RANDALL BYERS C \& PEEK M. 1974. A technique for analysis of utilization-availability data. J. Wildl Manage 38: 541-545.

NEWBOLD TA \& MACMAHON JA. 2014. Determinants of habitat selection by Desert Horned lizards (Phrynosoma platyrhinos): The importance of abiotic factors associated with vegetation structure. J Herpetol 48: 306-316.

PELEGRIN N \& BUCHER EH. 2012. Effects of habitat degradation on the lizard assemblage in the Arid Chaco, central Argentina. J Arid Environ 79: 13-19.

PIETREK AG, WALKER RS \& NOVARO AJ. 2009. Susceptibility of lizards to predation under two levels of vegetative cover. J Arid Environ 73: 574-577.

QUIRT KC, BLOUIN-DEMERS G, HOWES BJ \& LOUGHEED SC. 2006. Microhabitat selection of five-lined skinks in northern peripheral populations. J Herpetol 40: 335-342. 
RADDER RS, SAIDAPUR SK \& SHANBHAG BA. 2005. Population density, microhabitat use and activity pattern of the Indian rock lizard, Psammophilus dorsalis (Agamidae). Curr Sci 89: 560-566.

R CORE TEAM. 2018. R: a language and environment for statistical computing. R Foundation for Statistical Computing, Vienna, Austria. http://www.R-project.org.

REINERT HK. 1993. Habitat selection in snakes. Snakes: Ecology and Behaviour. McGraw-Hill. New York.

RIBEIRO LB, SOUSA BM \& GOMIDES SC. 2009. Range structure, microhabitat use, and activity patterns of the saxicolous lizard Tropidurus torquatus (Tropiduridae ) on a rock outcrop in Mina Gerais, Brazil. Rev Chil Hist Nat 82: 577-588.

SABO JL. 2003. Hot rocks or no hot rocks: overnight retreat availability and selection by a diurnal lizard. Oecologia 136: 329-335.

SAWYER H, KAUFFMAN MJ \& NIELSON RM. 2009. Influence of well pad activity on winter habitat selection patterns of Mule Deer. J Wildl Manage 73: 1052-1061.

SCHULTE JA, LOSOS JB, CRUZ FB \& NúÑEZ H. 2004. The relationship between morphology, escape behaviour and microhabitat occupation in the lizard clade Liolaemus (Iguanidae: Tropidurinae*: Liolaemini). J Evol Biol 17: 408-420.

SINERVO B ET AL. 2010. Erosion of lizard diversity by climate change and altered thermal niches. Science 328 : 894-899.

SMITH G \& BALLINGER R. 2001. The ecological consequences of habitat and microhabitat use in lizards: a review. Contemp Herpetol 3: 1-36.

SOKAL RR \& ROHLF FJ. 1995. Biometry, $3^{\text {rd }}$ Ed, Freeman, New York, p. 887.

STAMPS JA. 1983. The relationship between ontogenetic habitat shifts, competition and predator avoidance in juvenile lizard (Anolis aeneus). Behav Ecol Sociobiol 12: 19-33.

STELLATELLI OA, BLOCK C, VEGA LE \& CRUZ FB. 2014. Responses of two sympatric sand lizards to exotic forestations in the coastal dunes of Argentina: Some implications for conservation. Wildl Res 41: 480-489.

STELLATELLI OA, VEGA LE, BLOCK C \& CRUZ FB. 2013. Effects on the thermoregulatory efficiency of two native lizards as a consequence of the habitat modification by the introduction of the exotic tree Acacia longifolia. J Therm Biol 38: 135-142.

SUNDAY JM, BATES AE, KEARNEY M, COLWELL RK, DULVY NK, LONGINO JT \& HUEY RB. 2014. Thermal-safety margins and the necessity of thermoregulatory behavior across latitude and elevation. Proc Natl Acad Sci USA 111: 5610-5615.

VAN DAMME R, BAUWENS D, CASTILLA AM \& VERHEYEN RF. 1989. Altitudinal variation of the thermal biology and running performance in the lizard Podarcis tiliguerta. Oecologia 80: 516-524.

VICENZI N, CORBALÁN V, MILES D, SINERVO B \& IBARGÜENGOYTÍA N. 2017. Range increment or range detriment? Predicting potential changes in distribution caused by climate change for the endemic high-Andean lizard Phymaturus palluma. Biol Conserv 206: 151-160.

VICENZI N, IBARGÜENGOYTÍA N \& CORBALÁN V. 2019. Activity patterns and thermoregulatory behavior of the viviparous lizard Phymaturus palluma, in Aconcagua Provincial Park, Argentine Andes. Herpetol Conserv Biol 14: 337-348.

VIDELA F. 1982. Observaciones etológicas preliminares sobre Phymaturus palluma (Reptilia- Iguanidae) del Roquedal Precordillerano Mendocino. Bol Mus Cs Nat y Antrop "C Moyano" 3: 57-62.

VITT LJ \& CALDWELL P. 2008. Herpetology: An introductory biology of amphibians and reptiles, $3^{\text {rd }}$ Ed., Academic Press. California, USA, p. 720.

WIENS TS, DALE BC, BOYCE MS \& KERSHAW GP. 2008. Three way k-fold cross-validation of resource selection functions. Ecol Modell 212: 244-255.

ZUCKER N. 1986. Perch height preferences of male and female tree lizards, Urosaurus ornatus: A matter of food competition or social role? J Herpetol 20: 547-553. 


\section{How to cite}

VICENZI N, MASSARELI R, IBARGÜENGOYTÍA N \& CORBALÁN V. 2021. Basking and retreat site selection of Phymaturus palluma, a rockdwelling lizard in the Highlands of Aconcagua. An Acad Bras Cienc 93: e20190662. DOI 10.1590/0001-3765202120190662.

Manuscript received on June 7, 2019;

accepted for publication on January 27, 2020

\section{NADIA VICENZI ${ }^{1,2}$}

https://orcid.org/0000-0001-7309-7294

\section{RUBÉN MASSARELLI ${ }^{3}$}

https://orcid.org/0000-0001-7738-2439

\section{NORA IBARGÜENGOYTÍA 4,5}

https://orcid.org/0000-0002-1959-2718

\section{VALERIA CORBALÁN ${ }^{1}$}

https://orcid.org/0000-0002-3977-392X

${ }^{1}$ Instituto Argentino de Investigaciones en Zonas

Áridas, Consejo Nacional de Investigaciones

Científicas y Técnicas (IADIZA-CONICET), Av. Ruiz

Leal s/n, 5500 Ciudad de Mendoza, Argentina

${ }^{2}$ Facultad de Ciencias Exactas y Naturales,

Universidad Nacional de Cuyo, Padre Contreras

1300, 5500 Ciudad de Mendoza, Argentina

${ }^{3}$ Dirección de Recursos Naturales Renovables,

Secretaría de Ambiente y Ordenamiento Territorial, Av.

L. Peltier 351, 5500 Ciudad de Mendoza, Argentina

${ }^{4}$ Instituto de Investigaciones en Biodiversidad y

Medioambiente, Consejo Nacional de Investigaciones

Científicas y Técnicas (INIBIOMA-CONICET),

Quintral 1250, 8400 Río Negro, Argentina

${ }^{5}$ Departamento de Zoología, Centro Regional

Universitario Bariloche, Universidad del Comahue,

Quintral 1250, 8400 Río Negro, Argentina

Correspondence to: Nadia Vicenzi

E-mail:navicenzi@gmail.com

\section{Author contributions}

NV, VC and NRI conceived and designed research; NV and RM performed research and analyzed data; NV wrote the paper; and VC, NRI and RM helped revise the manuscript.

\section{(cc) BY}

